\title{
The Relationship between Economic Growth, FDI, Trade, Labor, Capital Formation in Indonesia
}

\author{
Amelia Budiharto $^{1}$, Suyanto $^{2}$, Aluisius Hery Pratono ${ }^{3}$ \\ ${ }^{1}$ amelia.budiharto@gmail.com \\ ${ }^{2}$ suyantodstaff.ubaya.ac.id \\ ${ }^{3}$ hpratono@gmail.com
}

Faculty of Business and Economic, Universitas Surabaya, Indonesia

\begin{abstract}
This paper aims to examine the relationship between foreign direct investment, trade, labor, capital formation and economic growth in Indonesia. The study is conducted by establishing annual time series data covering period of 1985-2015 and examine using autoregressive distributed lag (ARDL). The ARDL bound test approach for cointegration reveal that there are three proposed model of cointegration among variables specifically when direct investment, trade, and capital formation as dependent variables. The long-run test associated with the cointegration model confirming at least two variables are significantly affect the dependent variable in each cointegration model. The result of error correction term indicates that there is uniformity of convergence towards the equilibrium point in the long-run term for all three models.

Labor confirmed as the important indicators to attract foreign direct investment and to improve production scales for trade activities. The study also found that foreign direct investment is the main contributor in capital formation injection. The study suggests that the policy and government efforts to build competent human capital as preparation for future generation is widely believe a wise option. Investors pro-policy and liberalization should be promote continuously to open more gate for new investors in establishing business in Indonesia. Simultaneously, the technological spill over derive from FDI can be absorb and adopt by the local labor force.
\end{abstract}

Keywords - economic growth, FDI, trade, labor, capital formation

\section{INTRODUCTION}

During the past three decades, international trade and foreign direct investment (FDI) have become increasingly important factors in the economic growth process. As the economic literature, endogenous growth model, proposed that technological spill over and externalities is the primary contributor of economic growth. There are few channels of technological spill over in the host country, including international trade and foreign direct investment as for the example. The economic theory explained that FDI enhances economic growth through capital accumulation and transfer of technology augments the stock of knowledge in the recipient country through labor training and skill acquisition, new management practices and organizational arrangements [7]. The technological spills over from advanced to lagging countries from the flow of FDI is encourage a country in the adoption of superior technology, transferring knowledge from foreign entities to the local firm. As a result, it is aim to improve the productivity, minimize the waste from existing resources, and increase the export capacity. As the business scales growing and the FDI inflow fluidly coming to the host country, the creation of new jobs is able to bring the unemployment number down.

International trade also plays the role of upgrading skills through the important and adoption of superior production technology and innovation. A recent study from [2] that multinational trade serves as transmission belt to transferred the technological knowledge from the develop to developing countries. The exporters may gain knowledge transfer either by acting as subcontractors to foreign enterprises or through international markets competition which gives the opportunity to learn developed production technology and excellent innovation to be imitated or adopted.

The process of multinational trade is will only happen through the liberalization of trade openness. The preposition that trade openness impact positively on economic growth is supported by [16], [13]; they stated that countries that more opened to the rest of the world would be positively and significant leading mainly due to the accumulation of physical capital and technological transfer. In view of comparative advantage theory of HecksherOhlin, openness can be beneficial in improving economic performance of a country. Other fact, openness will enhance the capital inflow to a 
country and thus will accelerate capital accumulation and transfer technology which is considered the main components in strengthening the economic growth as defined by endogenous growth theory. In brief, the process of trade liberalization not only increases trade but also foreign direct investment. In order to improving trade performance internationally, the investment is which is absolutely necessary.

In sum, both FDI inflows and trade openness promote economic growth have been widely recognized as a very important factors in the economic growth process, however, the effect of FDI, trade and technological spill over may vary from country to country and it is also depends crucially on the stock of human capital and their absorptive capacity in the host country. It is expected that a nation can generate profits that can accumulate income and capital formation value. Capital formation is used as a fund for national development programme in the country. Therefore, the vicious cycle of poverty can be broken and economic development can be improved.

Endogenous model is develop based on the underlying fact that the previous neoclassical model is only reporting the impact of technological progress on economic growth, but does not able to explore the determinants of technological progress. The new growth theory after awhile established exploring the determinants and impacts of technological progress. It focused mainly on incentives that drive innovation, invention, and creation as a main engine of growth. The main difference between the neoclassical theory and the new growth theory is the technology function. While the former assumes technological progress to be exogenous, the latter recognizes technological progress as a form of investment spill over arising from different inputs. The main implication of the endogenous growth theory is that policies which induce international trade, competition, change and innovation will promote growth. Conversely, policies which have the effect of restricting or slowing change by protecting or favouring particular existing industries are likely to slow growth over time [2].

Since the endogenous growth explains the endogeneity of technological progress which can driven from many different sources, the technological progress is not represent by a single constant rate parameter anymore in the production function assumption. It is leading to modification of the production function which is differ based on the researcher model and assumption. There are several theory proposed the sources of technological spill over, such as science [25], human capital [18], human capital [10], foreign direct investment [27]. All of those technological progress model have calibrated [16] model that assume endogenous technological progress is the main engine of economic growth in long run and diffuse the technology in economic models of endogenous growth.

As the different concept behind neo-classical and endogenous growth model, some theory that explain foreign direct investment and international trade relationship with economic growth as well contrasting each other. According to the neoclassical models, it is confine that FDI can only affect growth in the short run because of diminishing returns of capital in the long run. The endogenous model on the contrary made it possible to modelling FDI as promoting economic growth even in the long run through the permanent knowledge transfer that accompanies FDI. As an externality, this knowledge transfer, with other externalities, will account for the non-diminishing returns that result in long run growth [7]. Hence, if growth determinants, including FDI, are made endogenous in the model, long run effects of FDI will follow. A particular channel whereby technology spills over from advanced to lagging countries is comes along with the flow of FDI [4].

The empirical literature studying the impact of FDI in Indonesia show that FDI inflows has positive impact towards the GDP value. Using single regression model covered 30 years period from 1970 to 2000, [23] identify that the increase of FDI value will be followed by the improvement of Indonesia's GDP. Other study from developing country, Nepal, also similarly found that foreign direct investment have dynamic positive significant effect to promote economic growth. The author implies that least developed country should reduce barriers of investment to attract foreign investors and promote economic growth [19]. 
The new growth theory also concern regarding the degree of trade openness regulation. According to economic theory, this restrictiveness, this lack of trade openness, will have an economic effect of slowing economic development/growth. Conversely, trade openness will have an economic effect of increasing economic development and growth. Reference [21] proposes an idea that less-restricted policies of trade are a window to open access with the outside world. Buckley explained that open regulation in developing country is likely stimulate intense trading activities, given access of market entry for international exporters. Trade is well known as important determinant of technological transfer and opportunity to explore new production technological knowledge [15]. Reference [15] explained that technological progress happen through upgrading skills and adoption of superior production technology. The new technology adoption by domestic firms aims to brings benefits including existing resources efficiently, increasing the range and quality of intermediate goods, create new variation of products. In the long-run, trade can enhances capital accumulation as the increases of level of exports.

However, the empirical evidence shows an opposite result. Reference [24] examines the impact of financial and trade openness towards Indonesia economy. Using secondary data from 1980 to 2005, [24] discover that adapting open economy give a drawback to the local economy. Trade openness lead to weaken competitiveness of Indonesian products relatively to foreign products. The increase number of imported product will affect the demand of local product and at the end the local firm's output is plummeted. Financial openness leads to vulnerable capital reversal which endanger economic performance. The author identify that high demand of import commodities cause high demand of foreign currency which is weaken the rupiah. As a result, the rupiah exchange is weaken from time to time. It is also cause capital unbalance since the rising value of import is not compensated with an increasing number of exports. Similar study done by [3] which examine the linkages of FDI, trade openness, capital formation and economic growth in Bangladesh from 1986-2008 also obtained that trade openness has negative significant effect by diminishing the rates of economic growth.

There are several strong opposite theory regarding the interaction between trade and FDI. Reference [7] study concludes that trade and FDI interaction can affect negatively, however this phenomenon vary from country to country. According [12], FDI and trade has sub-tutionary relationship, which means one variable rising can cause the downfall of another one. Trade define as less riskier option for marketing products in new country while contractual strategies is way more complicated and highly dependent on the host country condition including politics, safety, inflation, bureaucracy, and many more. However, many studies argue that FDI and trade has complimentary relationship, which explained that export drives inward FDI and inward FDI drive technological spill over and push export level, this cycle will likely continue repeatly as follow [1].

Reference [17] examines the relationship between International trade and FDI in Indonesia which is cover from 1996 until 2014. The study identify that there is two ways relationship between FDI and trade where the value of FDI affecting the value of trade. In short-term, FDI affect trade negatively while in the long-run FDI is positively increase the value of trade.

As regards the connection with capital formation, [5] mention that capital formation is an indispensable thing for any country to become self sufficient and less dependent of foreign resources, expansion of job opportunities, make better use of natural resources, obtain high quality goods, and in the long-run brings economic growth with major increasing in living standard of the people. Reference [14] vicious cycle of poverty model also attempts to explains the state of affairs of capital formation effect on economic development. The circle perpetuates that low income will cause low savings, low investment, capital deficiency and low productivity. Basically, in an economy, investment does not depend only on saving, but also on ability to invest and willingness to invest. This circle will repeatly over, the chain can only be break by finding a breakthrough [14].

The concept of capital investment is also really important to transformed the labor force into human 
capital with effective inputs of education, health and moral values. The transformation of raw human resource into highly productive human resource with these inputs is the process of human capital formation. The problem of scarcity of tangible capital in the labor surplus countries can be resolved by accelerating the rate of human capital formation with both private and public investment in education and health sectors of their national economies. The tangible financial capital is an effective instrument of promoting economic growth of the nation. The intangible human capital, on the other hand, is an instrument of promoting comprehensive development of the nation because human capital is directly related to human development, and when there is human development, the qualitative and quantitative progress of the nation is inevitable [20].

As widely believe that FDI and trade stimulate positive contribution to the growth and improve the standard of living condition or income level, some economist reject the idea by arguing that the increase of income level can create a drawback in the economy and make a bubble burst of worst economic shock transaction. In short time-series, demand of consumption is tremendously rising which is later affected the products allocation between the local and international market [8]. The exchange rate can be affected from the volatility of import value [24]. This is explained in the new growth theory that GDP measurement is not the stand alone factor which affects growth and social progress.

Economic theory and empirical evidence may have contrasting result which is can be an important sources and fact of the truth condition in the surface. It is an valuable sources as a contribution of the existing theory by testing and comparing with the empirical evidence gather from the past events.

\section{METHODS}

Issues examined in this study is limited to the annual time series data on economic growth, FDI, trade, labor and capital formation covering the year 1980-2015 in Indonesia. Gross domestic product (GDP) per capita is taken as economic growth indicator. Data taken from IMF World Economy Outlook. Foreign direct investment (FDI) net inflows is measured as percentage of GDP value in the consecutive year. Data resources taken from World Bank. Trade openness measured by percentage of total sum of export and import value from GDP. Data set is taken from Indonesia's Central Bureau of Statistics. Labor measured by the total labor force with assumption of million people is equal to 1. Data also taken from Indonesia's Central Bureau of Statistics. Capital formation is measured by Gross Fixed Capital Formation (GFCF) value as percentage to the GDP value. GFCF data gather from Bank Indonesia. All data used in this study is expressed in current US dollar denomination.

The model developed in this study underlying from Cobb-Douglas production function as follow : $\mathrm{Yt}=\mathrm{AK} \alpha \mathrm{L} \alpha-1$

where, $\mathrm{Y}$ is the gross domestic product in an economy in a given period $\mathrm{t}$, and $\mathrm{K}$ and $\mathrm{L}$ are gross fixed capital formation and labor force as factors of production during the same period t. According to the endogenous growth model, the technological progress, A, is augmented from foreign direct investment and trade openness factors. The function is modified as follow:

$\mathrm{Yt}=\mathrm{K} \beta 1 . \mathrm{L} \beta 2 . \mathrm{F} \beta 3 . \mathrm{T} \beta 4$

where, $\mathrm{Y}$ is the gross domestic product and $\mathrm{K}, \mathrm{L}$, F, Trepresent gross fixed capital formation, labor force, foreign direct investment, and trade openness.

The equation 2 can be rewritten in logarithm natural form as follow:

$\ln Y t=\ln ((\mathrm{Kt}) \beta 1 .(\mathrm{Lt}) \beta 2 .(\mathrm{Ft}) \beta 3 .(\mathrm{Tt}) \beta 4)$

then subtracting the $\log$ squared as dependent parameter in front of variables.

$\ln Y \mathrm{t}=\beta 1 \cdot \ln (\mathrm{Kt})+\beta 2 \cdot \ln (\mathrm{Lt})+\beta 3 \cdot \ln (\mathrm{Ft})+\beta 4 \cdot \ln (\mathrm{Tt})$

In capturing this variables outside the variable, the error term and constant is included in the form, the equation can be written as follow :

$$
\begin{aligned}
& \ln Y \mathrm{t}=\alpha+\beta 1 \cdot \ln (\mathrm{Kt})+\beta 2 \cdot \ln (\mathrm{Lt})+\beta 3 \cdot \ln (\mathrm{Ft})+ \\
& \beta 4 \cdot \ln (\mathrm{Tt})+\varepsilon t
\end{aligned}
$$

where, Y represent GDP per capita, F for FDI over GDP in percentage, $\mathrm{T}$ is degree of trade openness over GDP percentage, $\mathrm{K}$ is the gross fixed capital formation over GDP percentage, and $\mathrm{L}$ is the 
total labor force. The expected signs of the parameters are: $\beta 1 \neq \beta 2 \neq \beta 3 \neq \beta 4 \neq \beta 5 \neq 0$. The error-term $(\varepsilon)$ is assumed to be independently and identically distributed. The subscript $(t)$ indexes time.

The study proceeds from the stationarity test of time series data using unit root test with a model ADF test, Phillips-Perron test, and Dickey-Fuller test. The unit root test suppose to determine the stationary rate level or lag level of variables. If variables is found non-stationary at zero level difference, the test is re-conduct integrated in order one to induce stationarity. In second step, the presence of cointegration is determine using autoregressive distributed lag (ARDL) bound test. The granger causality is run after to analyze the presence of long-run cointegration amongst the variables. The short-run equilibrium and long-run convergency is construct using vector error correction model by adding error correction term.

The ARDL model that used in this study is expressed as follows:

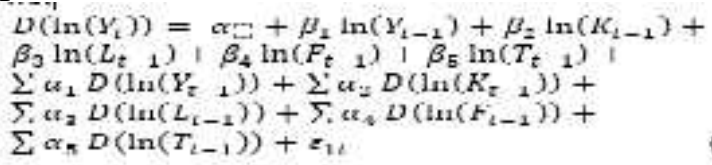

Sign of D is meaning of the data is integrated in the next level order and all taken to one year period before the consecutive related year.

$$
\begin{aligned}
D\left(\ln \left(Y_{t}\right)\right)=\alpha_{t} & +\beta_{1} \ln \left(Y_{t-1}\right)+\beta_{2} \ln \left(K_{t-1}\right) \\
& +\beta_{3} \ln \left(L_{t-1}\right)+\beta_{4} \ln \left(F_{t-1}\right) \\
& +\beta_{5} \ln \left(T_{t-1}\right)+\beta_{6} \mathrm{ECT}_{-1} \\
& +\sum \alpha_{1} D\left(\ln \left(Y_{t-1}\right)\right) \\
& +\sum \alpha_{2} D\left(\ln \left(K_{t-1}\right)\right) \\
& +\sum \alpha_{3} D\left(\ln \left(T_{t-1}\right)\right) \\
& +\sum \alpha_{4} D\left(\ln \left(F_{t-1}\right)\right) \\
& +\sum \alpha_{5} D\left(\ln \left(T_{t-1}\right)\right) \\
& +\sum \alpha_{6} D\left(\ln \left(E C T_{-1}\right)\right)+\varepsilon_{1 \mathrm{t}}
\end{aligned}
$$

The error correction term (ECT) is added to the parameter as resulted to motion the short-run dynamic coefficient is associated with the long-run relationship obtained.

\section{RESULTS}

\section{A. Unit Root Test Result}

The result of the stationary test given on Table I. Maximum of 1 Schwarz Information Criterion (SIC) lag length is used based on the log likelihood determination. The unit root is tested using augmented Dickey Fuller (ADF) test, Phillip-Perron (PP) test, and Dickey-Fuller generalized least square (DFGLS) de-trending test. The result show that all variables are not stationer at zero level difference.

TABLE I

UNIT ROOT TESTS AT LOG LEVELS OF VARIABLES

\begin{tabular}{|c|c|c|c|c|c|c|}
\hline \multirow{2}{*}{$\begin{array}{c}\text { Variabl } \\
\mathbf{e}\end{array}$} & \multicolumn{2}{|c|}{ ADF test } & \multicolumn{2}{|c|}{ PP test } & \multicolumn{2}{|c|}{ DFGLS test } \\
\cline { 2 - 7 } & $\boldsymbol{t}$-stats & $\begin{array}{c}\text { Critic } \\
\text { al } \\
\text { value } \\
\text { at 1\% }\end{array}$ & t-stats & $\begin{array}{c}\text { Critic } \\
\text { al } \\
\text { value } \\
\text { at 1\% }\end{array}$ & t-stats & $\begin{array}{c}\text { Critic } \\
\text { al } \\
\text { value } \\
\text { at 1\% }\end{array}$ \\
\hline $\ln (\mathrm{Y})$ & -0.19 & -3.63 & -0.09 & -3.64 & -0.21 & -2.63 \\
\hline $\ln (\mathrm{K})$ & -1.62 & -3.63 & -1.41 & -3.64 & -1.49 & -2.63 \\
\hline $\ln (\mathrm{L})$ & -1.40 & -3.62 & -1.49 & -3.64 & -0.22 & -2.63 \\
\hline $\ln (\mathrm{F})$ & -2.38 & -3.63 & -2.16 & -3.64 & -2.35 & -2.63 \\
\hline $\ln (\mathrm{T})$ & -3.56 & -3.62 & -3.63 & -3.64 & -3.61 & -2.63 \\
\hline
\end{tabular}

Since the stationarity not yet realized, it is necessary to re-conduct the test (ADF test, PhillipsPerron test, and Dickey-Fuller test) which applied to the first difference to induce the stationarity circumstances of the data series. The final result given on the Table II shows that the null hypothesis of non stationary for all variables used in this study was rejected. Therefore, it is essential to conclude that all variables was integrated in order one or can be written as I (1).

TABLE II

UNIT ROOT TESTS ON FIRST DIFFERENCE AT LOG LEVELS OF VARIABLES

\begin{tabular}{|c|c|c|c|c|c|c|}
\hline \multirow{2}{*}{$\begin{array}{c}\text { Variabl } \\
\text { e }\end{array}$} & \multicolumn{2}{|c|}{ ADF test } & \multicolumn{2}{c|}{ PP test } & \multicolumn{2}{c|}{ DFGLS test } \\
\cline { 2 - 7 } & t-stats & $\begin{array}{c}\text { Critic } \\
\text { al } \\
\text { value } \\
\text { at 1\% }\end{array}$ & t-stats & $\begin{array}{c}\text { Critic } \\
\text { al } \\
\text { value } \\
\text { at 1\% }\end{array}$ & t-stats & $\begin{array}{c}\text { Critic } \\
\text { al } \\
\text { value } \\
\text { at 1\% }\end{array}$ \\
\hline $\ln (\mathrm{Y})$ & -4.09 & -3.64 & -4.07 & -3.64 & -4.13 & -2.63 \\
\hline $\ln (\mathrm{K})$ & -4.05 & -3.64 & -4.01 & -3.64 & -3.51 & -2.63 \\
\hline $\ln (\mathrm{L})$ & -6.15 & -3.64 & -6.14 & -3.64 & -5.68 & -2.63 \\
\hline $\ln (\mathrm{F})$ & -5.10 & -3.64 & -5.08 & -3.64 & -5.16 & -2.63 \\
\hline $\ln (\mathrm{T})$ & -8.67 & -3.64 & -9.36 & -3.64 & -8.44 & -2.63 \\
\hline
\end{tabular}

B. Cointegration Result under Autoregressive Distributed Lag (ARDL) bound test.

The bound test based on F-statistics was conducted under assumption on null hypothesis of no integration. The short span data was tested using Akaike information criteria (AIC) with maximum order 3 for conditional ARDL vector error 
correction model. The variable consider as dependent variable upon ARDL-OLS regression test. Table III show the result of F-statistics, the null hypothesis of no regression is rejected only if test stat value exceeds the $1 \%$ upper critical value.

Based on the analysis result it is found out that the gross domestic product, trade, and gross fixed capital formation $\mathrm{F}$ value stats exceed the $1 \%$ upper critical bound which indicates that there are longrun relationship among variables when foreign direct investment, trade, and gross fixed capital formation are the dependent variable.

TABLE III

ARDL BOUND TEST

\begin{tabular}{|c|c|c|c|}
\hline $\begin{array}{l}\text { Dependent } \\
\text { variable }\end{array}$ & $\begin{array}{l}\text { AIC } \\
\text { lags }\end{array}$ & F-statistic & Decision \\
\hline $\mathrm{F}_{\mathrm{Y}}(\mathrm{Y} / \mathrm{F}, \mathrm{K}, \mathrm{L}, \mathrm{T})^{\mathrm{a}}$ & 3 & 2.39 & No cointegration \\
\hline $\mathrm{F}_{\mathrm{F}}(\mathrm{F} / \mathrm{Y}, \mathrm{K}, \mathrm{L}, \mathrm{T})^{\mathrm{b}}$ & 2 & 5.27 & Cointegration \\
\hline $\mathrm{F}_{\mathrm{K}}(\mathrm{K} / \mathrm{Y}, \mathrm{F}, \mathrm{L}, \mathrm{T})^{\mathrm{c}}$ & 3 & 6.37 & Cointegration \\
\hline $\mathrm{F}_{\mathrm{L}}(\mathrm{L} / \mathrm{Y}, \mathrm{K}, \mathrm{F}, \mathrm{T})^{\mathrm{d}}$ & 3 & 1.77 & No cointegration \\
\hline $\mathrm{F}_{\mathrm{T}}(\mathrm{T} / \mathrm{Y}, \mathrm{K}, \mathrm{L}, \mathrm{F})^{\mathrm{e}}$ & 3 & 16.13 & Cointegration \\
\hline \multicolumn{3}{|c|}{ Lower-bound critical value at } & \\
\hline \multicolumn{2}{|c|}{$\begin{array}{l}\text { Upper-bound critical value at } \\
1 \%\end{array}$} & 5.06 & \\
\hline
\end{tabular}

${ }^{a} F_{Y}$ is gross domestic product as dependent variable

${ }^{b} F_{F}$ is foreign direct investment as dependent variable

${ }^{\mathrm{c}} \mathrm{F}_{\mathrm{K}}$ is gross fixed capital formation as dependent variable

${ }^{\mathrm{d}} \mathrm{F}_{\mathrm{L}}$ is labor force as dependent variable

${ }^{\mathrm{e}} \mathrm{F}_{\mathrm{T}}$ is total trade as dependent variable

Once cointegration is established, the conditional ARDL can be estimated. There are three cointegration models that examine based on the cointegration results in previous bound test. The three models are listed below:

- FF $(\mathrm{F} / \mathrm{Y}, \mathrm{K}, \mathrm{L}, \mathrm{T})$, a condition when foreign direct investment prevail as dependent variable

- FT (T/Y,K,L,F) , a condition when trade prevail as dependent variable

- FK (K/Y,F,L,T) , a condition when capital formation prevail as dependent variable

The ARDL long-run causality test is conducted separately for every each cointegration model, which is a condition when only one dependent variable in act while the others are plot as independent variables. Three different and separate result expected to be uncover in this part.

\section{IV.DISCUSSION}

Table IV presents result of long-run causality test for each cointegrated model. Clearly, these tests indicate the presence of a long-run equilibrium relationship among variables, which at least two variables significantly affect the dependent variable.

From the result obtained in the table IV, it can be identify that the sign of positive (+) and negative (-) on the coefficient number was given to prescribed whether the significant variable has signed positively or negatively impacted to the dependent variable. While the t-statistics probability was used to determine the degree of partial significance of independent variable impacted the dependent variable in the long term. As a regards to the causal effect, unidirectional causal flow is evidence between at least two independent variables and one dependent variable.

Result from first model cointegration indicate that FDI is positive significantly affect by labor while trade is negative significantly affect FDI. It is clearly seen that demographic bonuses and low wages condition in Indonesia is currently the main attraction for foreign investors. Trade possibly become the substitution option to FDI when the trade of cost is exceed the trade of investment. Furthermore, the investors also did not able to see other favourable reason to invest in Indonesia including the market size. As the FDI value increasing, it is does not affect the trade value and vice versa.

The second cointegration model identify that labor positively significant while GDP is negative significant to the trade. Large labor force size may beneficially for a country to accelerate and expand the production capacity. The excess production can be shipped for export. On the other side, GDP is influenced negatively possibly due to the short reaction of new living standard and change consumption behaviour which create a tremendously rising of demand. A consecutive trend of rising in consumption can cause such a sufficiency policy from the government by implementing restricted quotas of import and export.

Third model identified that FDI, and capital formation jointly affect capital formation. FDI is 
positive significant to capital which possibly due to a great contribution in expanding the capital formation. By contrast, trade is negative significant to the capital formation may due imbalance number of import-export earnings which cause persistent negative trade balance. A severity of economic fluctuations in countries dependent on import create difficulty of obtaining finance and lead to chronic diminishing of national resources and financial instability.

All the R-squared coefficient confirmed the robustness of the model. The F-statistics indicates a strong feedback effect runs within the model particularly independent to dependent variable.

TABLE IV

ESTIMATED LONG-RUN COEFFICIENTS USING ARDL APPROACH

\begin{tabular}{|c|c|c|c|}
\hline Variable & $\begin{array}{c}\text { Model } 1 \\
\text { F }_{\mathbf{F}}(\mathbf{F} / \mathbf{Y}, \mathbf{K}, \mathbf{L}, \mathbf{T})\end{array}$ & $\begin{array}{c}\text { Model } 2 \\
\mathbf{F}_{\mathbf{T}} \\
(\mathbf{T} / \mathbf{Y}, \mathbf{F}, \mathbf{K}, \mathbf{L})\end{array}$ & $\begin{array}{c}\text { Model 3 } \\
\text { F }_{\mathbf{K}} \\
(\mathbf{K} / \mathbf{Y}, \mathbf{F}, \mathbf{L}, \mathbf{T})\end{array}$ \\
\hline Constant & $\begin{array}{c}2.9992 \\
(0.4863)\end{array}$ & $\begin{array}{c}26.495 \\
(0.0678)\end{array}$ & $\begin{array}{c}38.471 \\
(0.0001)\end{array}$ \\
\hline $\ln (Y)$ & $\begin{array}{l}-0.0001 \\
(0.7447)\end{array}$ & $\begin{array}{c}-0.0093 \\
(0.0001)^{\mathrm{a}}\end{array}$ & $\begin{array}{l}-0.0003 \\
(0.2167)\end{array}$ \\
\hline $\ln (\mathrm{K})$ & $\begin{array}{c}0.0692 \\
(0.5264)\end{array}$ & $\begin{array}{l}-0.5190 \\
(0.2666)\end{array}$ & - \\
\hline $\ln (\mathrm{L})$ & $\begin{array}{c}0.0387 \\
(0.1002)^{\mathrm{c}}\end{array}$ & $\begin{array}{c}0.4523 \\
(0.0001)^{\mathrm{a}}\end{array}$ & $\begin{array}{c}0.2038 \\
(0.1384)\end{array}$ \\
\hline $\ln (F)$ & - & $\begin{array}{c}2.0051 \\
(0.1181)\end{array}$ & $\begin{array}{c}2.827 \\
(0.0024)^{\mathrm{a}}\end{array}$ \\
\hline $\ln (\mathrm{T})$ & $\begin{array}{c}-0.1647 \\
(0.0062)^{\mathrm{a}}\end{array}$ & - & $\begin{array}{c}-0.6628 \\
(0.0249)^{b}\end{array}$ \\
\hline R-square & 0.817 & 0.901 & 0.792 \\
\hline F-statistics & $\begin{array}{c}13.975 \\
(0.000001)\end{array}$ & $\begin{array}{c}11.761 \\
(0.000003)\end{array}$ & $\begin{array}{c}6.365 \\
(0.000157)\end{array}$ \\
\hline $\begin{array}{c}\text { DW- } \\
\text { statistics }\end{array}$ & 1.773 & 1.750 & 2.332 \\
\hline
\end{tabular}

Notes :

numbers stated above are the coefficients and number in the bracket are probability of t-statistics

a significant at $1 \%$ level

${ }^{\mathrm{b}}$ significant at $5 \%$ level

${ }^{c}$ significant at $10 \%$ level

C. Short-run Equilibrium Test under Vector ErrorCorrection Model

Error correction model is established to analyze the error correction terms (ECT) as a determination point of long-run convergency runs in the process. The regression for the underlying ARDL fits very well and the model is globally significant at the 5\% level. Negative coefficient of error correction term confirmed that all three models show uniformity of convergency to the equilibrium point in the longrun term. Speed of convergency is categorized in rapid medium point which implies the convergency process in the system happen in the mean time of 210 years. The result of vector error correction model test is shows in the Table V.

TABLE V

VECM MODEL ESTIMATION USING ARDL APPROACH

\begin{tabular}{|c|c|c|c|}
\hline Variable & $\begin{array}{c}\text { Model 1 } \\
\text { F }_{\mathbf{F}}(\mathbf{F} / \mathbf{Y}, \mathbf{K}, \mathbf{L}, \mathbf{T})\end{array}$ & $\begin{array}{c}\text { Model } 2 \\
\mathbf{F}_{\mathbf{T}} \\
(\mathbf{T} / \mathbf{Y}, \mathbf{F}, \mathbf{K}, \mathbf{L})\end{array}$ & $\begin{array}{c}\text { Model 3 } \\
\text { F }_{\mathbf{K}} \\
(\mathbf{K} / \mathbf{Y}, \mathbf{F}, \mathbf{L}, \mathbf{T})\end{array}$ \\
\hline Constant & $\begin{array}{l}-0.3564 \\
(0.1649)\end{array}$ & $\begin{array}{l}-1.7621 \\
(0.5569) \\
\end{array}$ & $\begin{array}{c}0.9134 \\
(0.3175) \\
\end{array}$ \\
\hline $\ln (Y)$ & $\begin{array}{c}0.0008 \\
(0.1809) \\
\end{array}$ & $\begin{array}{c}-0.0175 \\
(0.0019)^{\mathrm{a}} \\
\end{array}$ & $\begin{array}{c}-0.0022 \\
(0.0681)^{\mathrm{c}} \\
\end{array}$ \\
\hline $\ln (\mathrm{K})$ & $\begin{array}{c}0.0681 \\
(0.4692)\end{array}$ & $\begin{array}{c}-0.5638 \\
(0.0108)^{\mathrm{b}}\end{array}$ & - \\
\hline $\ln (\mathrm{L})$ & $\begin{array}{c}0.1416 \\
(0.2618)\end{array}$ & $\begin{array}{c}1.0763 \\
(0.1815)\end{array}$ & $\begin{array}{c}0.5834 \\
(0.0533)^{\mathrm{c}}\end{array}$ \\
\hline $\ln (F)$ & - & $\begin{array}{c}5.8451 \\
(0.0001)^{\mathrm{a}}\end{array}$ & $\begin{array}{c}0.6802 \\
(0.1129) \\
\end{array}$ \\
\hline $\ln (T)$ & $\begin{array}{c}-0.0591 \\
(0.0268)^{\mathrm{b}}\end{array}$ & - & $\begin{array}{c}0.0596 \\
(0.1752)\end{array}$ \\
\hline ECT & $\begin{array}{l}-0.6230 \\
(0.0169) \\
\end{array}$ & $\begin{array}{l}-0.4596 \\
(0.0092) \\
\end{array}$ & $\begin{array}{l}-0.2922 \\
(0.0413) \\
\end{array}$ \\
\hline $\mathrm{R}$-square & 0.7704 & 0.9465 & 0.8900 \\
\hline $\begin{array}{c}\text { F- } \\
\text { statistics }\end{array}$ & $\begin{array}{c}4.7543 \\
(0.001903)\end{array}$ & $\begin{array}{c}12.8004 \\
(0.000016)\end{array}$ & $\begin{array}{c}4.2597 \\
(0.011572)\end{array}$ \\
\hline $\begin{array}{c}\text { DW- } \\
\text { statistics }\end{array}$ & 1.7816 & 2.2975 & 2.7862 \\
\hline
\end{tabular}

Notes :

numbers stated above are the coefficients and number in the bracket are probability of t-statistics

${ }^{a}$ significant at $1 \%$ level

${ }^{\mathrm{b}}$ significant at $5 \%$ level

${ }^{c}$ significant at $10 \%$ level

D. Serial Diagnostic Test

TABLE VI

SERIAL Diagnostic TEST

\begin{tabular}{|c|c|c|c|}
\hline & $\begin{array}{c}\text { Model 1 } \\
\mathbf{F}_{\mathbf{F}} \\
\text { (F/Y,K,L,T) }\end{array}$ & $\begin{array}{c}\text { Model 2 } \\
\mathbf{F}_{\mathbf{T}} \\
(\mathbf{T} / \mathbf{Y}, \mathbf{F}, \mathbf{K}, \mathbf{L})\end{array}$ & $\begin{array}{c}\text { Model 3 } \\
\mathbf{F}_{\mathbf{K}} \\
(\mathbf{K} / \mathbf{Y , F}, \mathbf{L}, \mathbf{T})\end{array}$ \\
\cline { 2 - 4 } & \multicolumn{3}{|c|}{$\boldsymbol{X}^{\mathbf{2}}$ Statistic (probability) } \\
\hline Breusch- & 16.538 & 13.353 & 17.907 \\
Godfrey & $(0.167)$ & $(0.770)$ & $(0.528)$ \\
\hline White test & 11.964 & 14.052 & 15.860 \\
& $(0.533)$ & $(0.725)$ & $(0.666)$ \\
\hline \multirow{2}{*}{ Jarque-bera } & 1.793 & 0.773 & 0.320 \\
& $(0.407)$ & $(0.679)$ & $(0.851)$ \\
\hline Ramsey & 27.055 & 34.195 & 31.185 \\
RESET & $(0.672)$ & $(0.455)$ & $(0.762)$ \\
\hline
\end{tabular}

Notes :

numbers stated above are the coefficients and number in the bracket are probability of t-statistics

All three models are passes all diagnostic tests against serial correlation (Durbin Watson test and 
Breusch- Godfrey test), heteroskedasticity (White heteroskedasticity test), and normality of errors (Jarque-Bera test). The Ramsey RESET test also suggests that the model is well specified. CUSUM and CUSUMSQ tests are applied to assess parameter stability.The results from all three models indicate the absence of any instability of the coefficients because the plot of the CUSUM and CUSUMSQ statistic fall inside the critical bands of the $5 \%$ confidence interval of parameter stability.
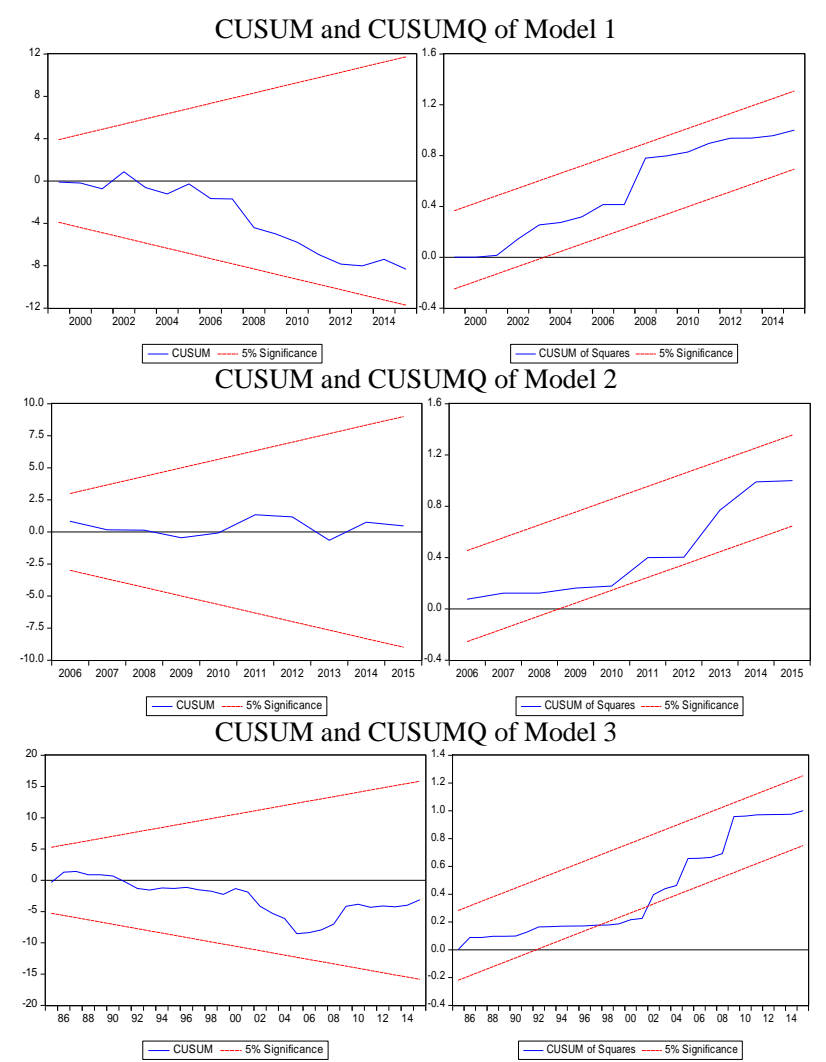

Fig.1. Parameter stability test

\section{CONCLUSIONS}

The study examine dynamic causal relationship among FDI, trade openness, capital formation, labor, and GDP per capita in Indonesia. ARDL model is used to identify the cointegration possibility and finding the interrelation among variable in the long-run. The long-run convergency is tested using VECM. The important implication of this study due to the fact of possible interrelations among variable that trigger a long-term positive effect towards economic growth. The result shows evidence of unidirectional relationship among variable.

As a result, labor has positive influenced to the trade and FDI which taken its as the ultimate significant factor in pushing entry of FDI in Indonesia for the past decade. A competitive and skilled labor force is an important matter that must be maintain to preserve the continuity of inward FDI in the future and beat the competition with fellow ASEAN countries as well to be reserve as prosper country for investment. The size and skills of labor also play critical role to attain desired output level and productivity. The vicious cycle of dependency on imported products can be cut off while on the other hand export product variety and volume can be boost with a greater human capital. Improvement of labor force capability is the key to maintain the sustainability of forward FDI and trade.

Government efforts to improve the quality of labor force that have been implemented in recent years deserve appreciation and endless support by promoting and establishing vocational school both in city and rural area is an alternative policy to equip societies with special abilities for expanding employment, producing high quality manufacturing, and preparing new generation to be ready for Indonesia's future economy. Moreover, vocational school aims to educate societies in rural area which still has poor education facilities, thus, knowledge inequality gap can be minimize over the time. Simultaneously promoting and investing human capital based on the demands of the labor market in Indonesia allow better social and economic result in the future.

With greater specialization, it is possible to discover a new technique to process domestic resources across sectors which lead to rapid product introduction. Encouragement of the creation of import product substitution by producing locally with own resources. Decrease the waste of resources.

FDI also revealed as the important contributor on capital formation. Issuing a more investor-friendly 
investment policy is one of the way to open the gate for new investors establish business in Indonesia. The government's pro-investors scheme that opened more sectors to foreign capital is expected to continue. Follow-up action including engagement of investors and local firms working together agreement with local industry is expected to create social economy's sustainable development condition rather than depends only from the capital injection inflow from FDI. Simultaneously, the spill over of technology from FDI can building more competence human capital in the nation.

\section{REFERENCES}

[1] J, Beghin. D, Roland-Holst. D, Van der Mensbrugghe. (2006). Trade and the Environment in General Equilibrium: Evidence from Developing Economies. Berlin: Springer Science \& Business Media.

[2] M, Belloumi. (2014). The relationship between trade, FDI and economic growth in Tunisia: An application of the ARDL model. Economic System, 38 (1), 269-287.

[3] B, K Adhikary. (2011). FDI, trade openness, capital formation, and economic growth in Bangladesh: A linkage analysis. International Journal of Business and Management, 6 (1), 1-21.

[4] M, Bengoa and B, Sanchez-Robles. (2003). Foreign direct investment, economic freedom and growth: New evidence from Latin America. European Journal of Political Economy, 19 (3), 529-545.

[5] W, Cohen. and D, Levinthal. (2012). Innovation and Learning: The Two Faces of R\&D. Economic Journal, 99 (2), 569-596.

[6] De Mello Jr. and Luiz, R. (1997). Foreign direct investment in developing countries: A selective survey. Journal of Development Studies, 34 (1), 1-34.

[7] De Mello Jr. and Luiz, R. (1999). Foreign direct investment-led growth evidence from time series and panel data. Oxford Economics Papers, 51 (2), 133-151.

[8] R, W Goldsmith. (1955). A study of savings in the United States. The Economic Journal, 67 (268), 710-713.

[9] G, M Grossman and E, Helpman. (1995). The politics of free-trade agreements. The American Economic Review, 85 (4), 1-50.

[10] G, M Grossman and H, Elhanan. (1991). Innovation and Growth in the Global Economy. Cambridge: MIT Press.

[11] I, Horstmann. and J, Markusen. (1992). Endogenous market structures international trade. Journal of International Economics, 32 (1-2), 109129.

[12] R, E. Lucas. (1988). On the mechanics of economic development. Journal of Monetary Economics, vol. 22, no. (1), 3-42.

[13] R, Nurkse. (1953). Problems of Capital Formation in Underdeveloped Countries. Basil Blackwell Publisher: Oxford.

[14] P, M Romer. (1990). Endogenous technological change. Journal of Political Economy, 98 (1), 71-102.

[15] P, M Romer. (1986). Increasing returns and long-run growth. Journal of Political Economy, 94 (5), 1002-1037.
[16] S, Safitri. (2014). International trade and foreign direct investment in Indonesia. Buletin Ilmiah Litbang Perdagangan, 8 (1), 93-116.

[17] T, W Schultz (1961). Investment in human capital. The American Economic Review, 51 (1), 1-17.

[18] B, K Adhikary. (2015). Dynamic effects of fdi, trade openness, capital formation and human capital on the economic growth rate in the least developed economies: Evidence from Nepal. International Journal of Trade, Economics and Finance, 6 (1), 1-7.

[19] M, Haq. (1996). Reflections on Human Development, Oxford: University Press.

[20] P, J Buckley. (1982). Multinational enterprises and economic analysis. London: Cambridge University Press.

[21] R, Barro. (1990), Government spending in a simple model of endogenous growth. Journal of Political Economy, 98 (5), 103-125.

[22] I, Bachtiar. (2003). Development stages and foreign direct investment: An analysis of Indonesia's recent experiences. Department of Economics, Colorado State University, unpublished Dissertation.

[23] I, Simorangkir. (2008). The openness and its impact to Indonesian economy. Bulletin of Monetary Economics and Banking, 10 (3).

[24] N, Rosenberg. (1963). Mandeville and laissez faire journal. Journal of the History of Ideas, 24 (2), 183-196.

[25] M, Abramovitz. (1955). Introduction to capital formation and economic growth. Capital Formation and Economic Growth, 55 (2), 116.

[26] R, J Barro. (1995). Economic Growth. New York: McGraw-Hill.

[27] G, S Becker. (1962). Investment in human capital: A theoretical analysis. Journal of Political Economy, 70 (5-2), 9-49.

[28] M, H Pesaran. Y, Shin. R, J Smith. (2001). Bounds testing approaches to the analysis of long run relationships. Journal of Applied Econometrics, 16 (3), 289-326.

[29] J, Poschl. and N, Foster-McGregor (2013). Productivity effects of knowledge transfers through labour mobility. FIW Working Paper, (117).

[30] X, Sala-i-Martin. and R, J Barro. (1995). Technological diffusion, convergence, and growth. NBER Working Paper, (5151).

[31] R, J Barro. and X, Sala-I-Martin. (1995). Economic Growth, New York: McGraw Hill.

[32] K, Shell. (1966). Toward a theory of inventive activity and capital accumulation. American Economic Review, 56 (2), 62-68.

[33] R, Solow. (1956). A contribution to the theory of economic growth. Quarterly Journal of Economics, 70 (1), 65-94.

[34] H, Van der Bergh. (1956). Economic Growth and Development, New York: McGraw-Hill.

[35] J, Y Wang. And M, Blomstrom. (1992). Foreign investment and technology transfer: A simple model. European Economic Review, 36 (1), 137-155.

[36] F, Harbison. and C, A Myers. (1964). Manpower and Education, Singapore: McGraw-Hill.

[37] A, Marshall. (1920). Principle of economics. Paris, Macmillan: 8th edition.

[38] H, Van der Bergh. (2001). Economic Growth and Development, New York, McGraw-Hill.

[39] J, S Duesenberry. (1949). Income, Saving and the Theory of Consumer Behaviour. Massachusetts, Harvard University Press.

[40] R, E Lipsey (2000). Inward FDI and economic growth in developing countries. Transnational Corporations, 9 (1), 61-95.

[41] J, Rapley. (1996). Understanding development: Theory and practice in the third world. Colorado, Lynne Rienner Publishers. 